\title{
INVESTMENT FEASIBILITY ANALYSIS IN PLANNING THE ESTABLISHMENT OF HEALTHY FOOD RESTAURANT AND CATERING BUSINESS "HEALTHY KITCHEN" OF PT DAPUR KULINER SEHAT
}

\author{
Aprilia Dian Naresywari*, Syah Tantri Yanuar R., Anindita Rina, Moelyono \\ Department of Management, University of Esa Unggul, Indonesia \\ *E-mail: diannaresywari@gmail.com \\ ORCID: 0000-0003-0972-6986
}

\begin{abstract}
Investment is a plan to invest resources that aims to obtain benefits in the future. It also applies to the establishment of healthy food restaurant and catering business. This study aims to determine the level of business feasibility in healthy food restaurant and catering "Healthy Kitchen" which is designed based on financial aspects. In addition, this study also aims to determine the rate of return of the business. The research was conducted to the business establishment plan of PT Dapur Kuliner Sehat. The data used in this study are secondary data in the form of raw material prices, sales projections for competitors in the healthy food culinary industry, and others. The data collection was conducted using observation and literature methods. The feasibility aspect used in this study is the financial aspect. The evaluation methods of the investment feasibility in financial aspects are Net Present Value (NPV), Payback Period (PP), Internal Rate of Return (IRR), Return on Investment (ROI), and investment sensitivity analysis. The findings showed that the plan in the establishment of PT Dapur Kuliner Sehat business has profitable business prospects so that it is feasible to be realized. That is indicated by the value of Payback Period method which showed that the Rate of Return on this healthy food restaurant and catering business is 2 years and 2 months. The Net Present Value method showed a positive value of IDR $86,662,424,281$. The IRR method showed a value of $109.13 \%$ which is greater than the bank interest rate. The Return on Investment (ROI) method showed a ROI value of $17 \%$, which means that the initial investment capital of IDR 2,138,855,361 will generate a net profit of $17 \%$. Meanwhile, in the calculation of investment sensitivity analysis, if there is a decrease in sales of $20 \%$, the value of the Internal Rate of Return (IRR) is $89.90 \%$, the Net Present Value (NPV) is IDR $72,298,091,942$, and the payback period is 3 years and 3 months.
\end{abstract}

\section{KEY WORDS}

Investment, feasibility analysis, business feasibility, healthy food, restaurant, catering.

The large number of people with degenerative diseases supports the need for healthy food consumption, considering that these patients must be more concerned with the food they consume. Based on data from the Health Research and Development Agency (2016), the number of consumers suffering degenerative diseases in Jakarta in 2016 included 26,572 people with diabetes, 403 people with chronic kidney, 70,538 people with hypertension, and 6,049 people with coronary hearts. Thus, the total number of consumers suffering from the diseases is 103,562 people per year. Based on data from the Health Research and Development Agency (2016), it was found that the number of people aged 40 years and over who were interested in consuming healthy food was 1,992,583. Meanwhile, the number of people with diabetes, chronic kidney disease, hypertension and coronary heart disease in Jakarta was 103,562 people. So, if the three data are summed, it can be concluded that the overall number of enthusiasts of healthy food is 2,096,145 people per year. Meanwhile, the number of restaurants and catering that provide healthy food in Jakarta is limited to only twelve restaurants and catering; which only serves 287,640 people per year. Based on that calculation, the average total demand is 2,096,145 people per year which is then reduced by the number of offers of 287,640 people per year. Therefore, there is still a gap between requests and offers of 1,808,505 people per year. Therefore, it can be 
concluded that there is still a gap between the number of requests and offers. It means that there are still problems in which the number of consumers who need healthy food cannot be supplied by the existing restaurants and catering. So, there is a considerable opportunity for newcomers in the healthy food industry to reach the number of unmet demands.

Based on the description of the above background, the author is willing to take existing business opportunities by establishing a healthy food restaurant and catering. However, only analyzing investment feasibility cannot determine whether or not the business is feasible. Thus, the author initially conducted a research about investment feasibility analysis in planning the establishment of healthy food restaurant and catering business "Healthy Kitchen" of PT Dapur Kuliner Sehat in Jakarta.

\section{THEORETICAL FRAMEWORK}

Payback Period (PP) Method. The Payback Period shows how long (in a few years) an investment will get a payback. Assessment of investment projects using this method is based on the duration of the investment to be covered with annual cash flow that does not include interest in the calculation.

Net Present Value (NPV) Method. Net Present Value (NPV) is a standard financial assessment method for long-term projects (De Reyck et. al., 2008; Shrieves \& Wachowicz Jr, 2001 ). This method uses a discount interest rate that will affect cash flow. The discount rate is the interest rate set by the government at commercial banks. This is different from the payback period which does not pay attention to the time value of money (Pasqual, et. al., 2001). In this method the present value of money is more valuable than the value of money in the future because it can be invested, saved, or deposited in a certain period of time and will get additional profits from its interest (Petković et. al., 2016). NPV can be calculated from the amount of net cash during the project period, with the general formula as follows:

$$
\mathrm{NPV}=\frac{1 \mathrm{st} \text { year net cash }}{(1+\mathrm{r})}+\frac{2 \text { nd year net cash }}{(1+\mathrm{r}) 2}+\ldots+\frac{\mathrm{n}-\mathrm{year} \text { net cash }}{(1+\mathrm{r}) \mathrm{n}}-\text { investment value }
$$

Where: $\mathrm{n}=$ investment project age; $r=$ interest rate; Net cash = net cash flow in that year; Investment value $=$ initial investment capital in the 0 year.

If the NPV is $>0$, the investment is considered as profitable and worthy of being accepted.

Internal Rate of Return (IRR) Method. In addition to using the NPV method, the Internal Rate Return (IRR) method is also used as a standard to assess the feasibility of long-term project investment (Hartman \& Schafrick, 2004). If the interest rate NPV method has been previously set, the IRR actually calculates the interest rate. IRR is defined as the discount rate when the NPV is zero. In other words, IRR is the interest rate when the value of the initial investment equals the future value of the cash flow throughout the life of the project; with the following formula:

$$
\mathrm{IRR}=\mathrm{P}-\mathrm{C} 1 \times \frac{\mathrm{P} 2-\mathrm{P} 1}{\mathrm{C} 2-\mathrm{C} 1}
$$

Where: $\mathrm{P} 1=$ interest rate $1 ; \mathrm{P} 2$ = interest rate $2 ; \mathrm{C} 1=$ value NPV $1 ; \mathrm{C} 2=$ value NPV 2.

If the IRR at the end of the project life is greater than the discount rate, the project can be accepted. If the IRR value gets bigger, then the profit of the project is also getting bigger. Return on Investment (ROI) Method. Return on investment is the ability of a company to generate profits that will be used to cover investments they are going to issue (Erdogmus et. al., 2004). This ratio sees the extent to which the productivity of the assets owned is able to provide returns as expected. This ratio is calculated by comparing the value of post-tax net income with the company's asset value. The calculation of the ratio of return on investment is assessed by the following formula:

$$
\text { ROI }=\frac{\text { Post }- \text { Tax Net Income }}{\text { Total Assets }}
$$


A good Return on Investment (ROI) value depends on the standards of the business industry. The Return on Investment (ROI) value of $10 \%$ is considered to be good.

Investment Sensitivity Analysis Method. Since the parameter values in technical economics studies commonly estimate the magnitude, it is clear that these values cannot avoid the error factor (Jovanović, 1999). It means that the values of these parameters may be larger or smaller than the estimation results obtained or changed at certain times. Changes that occur in parameter values will certainly result in changes at the level of output or results indicated by an alternative investment. These changes in the level of output or results allow decisions to change from one alternative to another. If changes in these factors or parameters cause a decision to change, then the decision is sensitive to changes in the value of these parameters or factors. To find out how sensitive a decision is to changes in factors or parameters that influence it, then any decision-making on technical economics should be accompanied by sensitivity analysis. This analysis will provide an overview of the extent to which a decision will be strong enough to deal with changes in the influencing factors or parameters. Sensitivity analysis is carried out by changing the value of a parameter at a certain time to then see how it affects the accessibility of an investment alternative. The parameters that can influence the changes in investment value include price changes, delay in project implementation, increase in costs, and inaccurate estimates of production results.

The objectives of Sensitivity Analysis include: 1) assessing what will happen with the results of the feasibility analysis of an investment or business activity if there is a change in the calculation of costs or benefits, 2) the feasibility analysis of a business or business calculation generally based on projections containing uncertainty about what will happen in the future, 3) analysis of post investment criteria is applied to see what will happen to the economic conditions and the results of business analysis in the changes or inaccuracies in the calculation of costs or benefits.

\section{RESULTS AND DISCUSSION}

Initial Investment Capital. In planning the value of the initial investment, PT Dapur Kuliner Sehat has planned the initial investment costs before the company runs. The investment aims to purchase assets and finance working capital needed to run the company's operational processes, building renovations and purchase company assets. Investment Capital which is needed for the initial establishment of PT Dapur Kuliner Sehat is IDR 2,138,855,361. Several types of investments needed by PT Dapur Kuliner Sehat and the size of the investment value can be seen in the following table.

The following is the amount of the initial investment needs of PT Dapur Kuliner Sehat.

Table 1 - Planning of Investment Costs

\begin{tabular}{|l|l|}
\hline \multicolumn{1}{|c|}{ Initial Investment Costs } & \multicolumn{1}{|c|}{ Total } \\
\hline Licensing Cost & IDR 12,300,000 \\
\hline Tool Purchase Cost & IDR 382,217,999 \\
\hline Information System (IT) and Mobile Application Costs & IDR 55,000,000 \\
\hline Building Rental Cost (1 year) & IDR 670,000,000 \\
\hline Renovation and Interior Design Costs & IDR 35,000,000 \\
\hline Equipment Purchase Cost & IDR 143,615,400 \\
\hline Logo Making Cost & IDR 1,500,000 \\
\hline Packaging Design Making Cost & IDR 1,890,000 \\
\hline Advertising, Promotion, and Pre-Operational Marketing Costs & IDR 10,640,000 \\
\hline Opening Ceremony Cost & IDR 11,000,000 \\
\hline Employee Salary and Benefit Costs & IDR 487,909,232 \\
\hline Employee Recruitment and Training Costs & IDR 25,553,000 \\
\hline Miscellaneous Costs & IDR 27,234,256 \\
\hline Total Working Capital & IDR 1,863,859,887 \\
\hline Save Money & IDR 274,995,475 \\
\hline Total of Investment & IDR 2,138,855,361 \\
\hline
\end{tabular}


Income. The net income of PT Dapur Kuliner Sehat comes from healthy food restaurant sales and healthy food catering package sales for one month plus other sales such as asset sales minus sales discounts and sales returns. The most possible estimated income of PT Dapur Kuliner Sehat is calculated from the expected sales volume of the target market share. The market share taken by the Healthy Culinary Kitchen is $10 \%$ of the number of opportunities in the healthy food culinary industry. Thus, the number of sales projections is adjusted to the market share, the production and service capacity of PT Dapur Kuliner Sehat. The following is a projection of the number of sales (portion) of PT Dapur Kuliner Sehat.

Table 2 - Calculation of the Number of Sold Portions

\begin{tabular}{|c|c|}
\hline Components & Total \\
\hline Request & IDR 2,096,145 \\
\hline Offer & IDR 287,640 \\
\hline Opportunity & IDR $1,808,505$ \\
\hline$\%$ of Opportunity & $10 \%$ \\
\hline Market Share & IDR 180,675 \\
\hline Total Sales Projection & \\
\hline
\end{tabular}

The following is a projection of net income for PT Dapur Kuliner Sehat.

Table 3 - Recapitulation of Company Income

\begin{tabular}{|c|c|}
\hline Year & Income \\
\hline 1 & IDR $18,254,687,900$ \\
\hline 2 & IDR $21,605,619,330$ \\
\hline 3 & IDR $26,336,634,793$ \\
\hline 4 & IDR $33,320,262,535$ \\
\hline 5 & IDR $80,505,056,548$ \\
\hline 6 & IDR $92,897,224,351$ \\
\hline 7 & IDR $108,373,625,954$ \\
\hline 8 & IDR $128,768,927,256$ \\
\hline 9 & IDR $299,070,720,152$ \\
\hline 10 & IDR 352,774,695,102 \\
\hline
\end{tabular}

Expenses. The costs incurred by PT Dapur Kuliner Sehat include sales cost, marketing cost, general and administrative expenses, and tax burden. Sales cost is cost incurred in connection with the sales business, such as the cost of promotional cost and advertising cost, raw material cost and operational cost.

The following is the detail of the sales cost of PT Dapur Kuliner Sehat.

Table 4 - Sales Cost of PT Dapur Kuliner Sehat

\begin{tabular}{|l|l|}
\hline Components & Costs in the $1^{\text {st }}$ Year \\
\hline Salary Expense & IDR $857,310,000$ \\
\hline Maintenance Expense & IDR $75,000,000$ \\
\hline Depreciation Expense & IDR $46,134,408$ \\
\hline Total of Fixed Costs & IDR $978,444,408$ \\
\hline Operating Cost & IDR $5,934,943,070$ \\
\hline Raw Material Cost & IDR $44,988,000$ \\
\hline Promotion and Advertising Cost & IDR $120,220,800$ \\
\hline Overhead & IDR $6,100,151,870$ \\
\hline Total of Operating Cost & IDR $7,078,596,278$ \\
\hline Total Cost &
\end{tabular}

The marketing department of PT Dapur Kuliner Sehat has targets to be achieved including increasing market share, increasing customer retention, increasing customer satisfaction, and increasing the brand. To achieve these targets, certain programs or strategies need to be implemented which of course need costs. The marketing costs needed are system maintenance cost and promotional cost.

The following is a detail of the marketing cost of PT Dapur Kuliner Sehat. 
Table 5 - Sales Cost of PT Dapur Kuliner Sehat

\begin{tabular}{|l|l|}
\hline Components & Costs in the $1^{\text {st }}$ Year \\
\hline Search Engine Optimization (SEO) Maintenance, Website & IDR $5,988,000$ \\
\hline Mobile Application & IDR $8,000,000$ \\
\hline Installation of Ads on Social Media such as Instagram, Facebook, Youtube, etc. & IDR $18,000,000$ \\
\hline Zomato & - \\
\hline Birthday Gift & IDR $8,100,000$ \\
\hline Discount & IDR $4,900,000$ \\
\hline Total Cost & IDR $44,988,000$ \\
\hline
\end{tabular}

During the company's operational period, PT Dapur Kuliner Sehat must bear administrative and general expenses. These expenses must be paid when the company produces the product or not; such as human resources (HR) cost and the purchasing office stationery cost. Human resources (HR) expenses consist of salary expenses and work requirements for the human resources department. Salary expenses consist of basic salary, meal allowance, transportation allowance, position allowance, old age insurance, health insurance, and pension insurance. There are also employee insurance costs, payment cost for the Social Security Organizing Agency (BPJS) and annual bonuses for employees. Meanwhile, the costs of other human resources (HR) departments are recruitment costs. The other costs are the telephone payment cost and the purchasing office stationery cost. The following is the details of administrative and general expenses of PT. Dapur Kuliner Sehat.

Table 6 - Administrative and General Expenses of PT Dapur Kuliner Sehat

\begin{tabular}{|l|l|}
\hline Components & Costs in the $1^{\text {st }}$ Year \\
\hline Salary & IDR $4,512,000,000$ \\
\hline Social Security Organizing Agency (BPJS) of Employment & IDR $216,919,812$ \\
\hline Social Security Organizing Agency (BPJS) of Health & IDR $98,739,216$ \\
\hline Insurance & IDR $315,600,000$ \\
\hline Holiday Allowance & IDR $207,100,000$ \\
\hline Bonus & IDR $203,760,000$ \\
\hline Training and Development & IDR $25,000,000$ \\
\hline Office Stationery & IDR $7,950,000$ \\
\hline Electricity Payment & IDR $72,000,000$ \\
\hline Telephone Payment & IDR 460,800 \\
\hline LPG Purchase & IDR $8,160,000$ \\
\hline Total Cost & IDR $5,667,689,828$ \\
\hline
\end{tabular}

PT Dapur Kuliner Sehat will fulfill company tax obligations. The tax in question is the Corporate Income Tax (PPB). The amount of PPB, according to the applicable provisions, is $25 \%$. In addition, PT Dapur Kuliner Sehat will also fulfill company obligations for income tax on employee salaries-based on the article 21-that will be calculated and paid for and reported by the company by issuing Tax Sector Letters (SSP) and Tax Annual Return (SPT) every month.

The following is the PT Dapur Kuliner Sehat's taxes:

Table 7 - Tax Burden of PT Dapur Kuliner Sehat

\begin{tabular}{|c|c|}
\hline Components & Costs in the $1^{\text {st }}$ Year \\
\hline Corporate Income Tax & IDR 35,268,474 \\
\hline Income Tax 21 & IDR 4,659,776 \\
\hline Total Cost & IDR 39,928,250 \\
\hline
\end{tabular}

Investment Feasibility Analysis of PT Dapur Kuliner Sehat. Based on our calculations, the payback period for investment capital of IDR 2,138,855,361 is 2 years and 2 months.

Based on the net present value calculation of PT Dapur Kuliner Sehat, it is found that the NPV is IDR $86,662,424,281$ or NPV $>0$. It means that the present value of total demand is greater than the present value of total costs, so that the investment is feasible.

Based on the calculation of the Internal Rate of Return of PT Dapur Kuliner Sehat, it is found that the IRR value is 109.13 percent. This value is greater than the discount value or 
bank loan interest rate of $15 \%$, so it is considered that this business project is profitable and feasible to run.

Based on the calculation of the Return on Investment of PT Dapur Kuliner Sehat that we have calculated previously, the first year has a value of $17 \%$. It means that the initial investment capital of IDR 2,138,855,361 will generate a net profit of $17 \%$, which is above the industry standard of $10 \%$. Therefore, that this business is worth to do investment.

The following is an illustration of the description of how the sensitivity analysis of PT Dapur Kuliner Sehat during the decrease in product sales by 20 percent.

Table 8 - Sensitivity Analysis with Scenario of Decreasing Sales by 20 Percent

\begin{tabular}{|l|l|l|}
\hline Description & Size & Total \\
\hline Based on the projection & - & 180,675 \\
\hline $\mathrm{NPV}^{*}$ ) & IDR & IDR $86,662,424,281$ \\
\hline IRR & $\%$ & $109.13 \%$ \\
\hline PBP & Year & 2 years and 2 months \\
\hline Description & Size & Total \\
\hline If the sales decrease by 20\% & - & 144,540 \\
\hline NPV ${ }^{*}$ ) & IDR & IDR 72,298,091,942 \\
\hline IRR & $\%$ & $89.90 \%$ \\
\hline PBP & Year & 3 years and 3 months \\
\hline
\end{tabular}

In this calculation of sensitivity analysis, PT Dapur Kuliner Sehat made an assumption of calculating a decrease in sales of $20 \%$ of the value of the previous sales scenario. The sales decline of $20 \%$ still shows a positive signal. Thus, the value of the company can still be maintained.

\section{CONCLUSION}

This business plan is feasible because it provides a high rate of return to its shareholders. This conclusion can be seen from the positive profit that has been recorded since the first year with an average growth of 103 percent, a positive Net Present Value of IDR $86,662,424,281$, the Internal Rate of Return (IRR) of 109.13 percent. That exceeds the cost of equity capital by 22 percent. In addition, dividends have been made since the first year of operation of 40 percent of net income after tax. Payback period ranges from 2 years and 2 months. Meanwhile, in the calculation of investment sensitivity analysis, if there is a decrease in sales of $20 \%$, the value of the Internal Rate of Return (IRR) is $89.90 \%$, the Net Present Value (NPV) is IDR $72,298,091,942$, and the payback period is 3 years and 3 months.

Thus, in terms of finance, this business plan is feasible to run. This research has shown that the investment feasibility analysis in the PT Dapur Kuliner Sehat business is very good from the financial aspects. This analysis shows that healthy food restaurant and catering business have good prospects. For further research, future researchers should explore the existing information in more detail so that the findings can be used as information material to develop healthy food restaurant and catering businesses.

Generally, there are still limitations in the business feasibility analysis of PT Dapur Kuliner Sehat (Restaurants and Catering "Healthy Kitchen"); among others, the analysis of competitor offers for healthy food restaurant and catering is calculated based on the secondary data, i.e. observations conducted by the researchers on the number of guests who came to the restaurant, not the primary data from competitors, i.e. data on the number of consumers and the amount of income.

\section{REFERENCES}

1. De Reyck, B., Degraeve, Z., \& Vandenborre, R. (2008). Project options valuation with net present value and decision tree analysis. European Journal of Operational Research, 184(1), 341-355. 
2. Shrieves, R. E., \& Wachowicz Jr, J. M. (2001). Free Cash Flow (FCF), Economic Value Added $\left(E A^{T M}\right)$, and Net Present Value (NPV):. A Reconciliation of Variations of Discounted-Cash-Flow (DCF) Valuation. The engineering economist, 46(1), 33-52.

3. Pasqual, J., Padilla, E., \& Jadotte, E. (2013). Equivalence of different profitability criteria with the net present value. International Journal of Production Economics, 142(1), 205210.

4. Petković, D., Shamshirband, S., Kamsin, A., Lee, M., Anicic, O., \& Nikolić, V. (2016). Survey of the most influential parameters on the wind farm net present value (NPV) by adaptive neuro-fuzzy approach. Renewable and Sustainable Energy Reviews, 57, 12701278.

5. Hartman, J. C., \& Schafrick, I. C. (2004). The relevant internal rate of return. The Engineering Economist, 49(2), 139-158.

6. Erdogmus, H., Favaro, J., \& Strigel, W. (2004). Return on investment. IEEE Software, 21(3), 18-22.

7. Jovanović, P. (1999). Application of sensitivity analysis in investment project evaluation under uncertainty and risk. International Journal of Project Management, 17(4), 217-222. 